\title{
INCREASING SELF EMPOWERMENT AND QUALITY OF LIFE OF PATIENTS WITH TYPE 2 DIABETES MELLITUS WITH DIABETES EMPOWERMENT EDUCATION BASED ON HEALTH PROMOTION MODEL
}

\author{
(Peningkatan Self Empowerment dan Kualitas Hidup Pasien Diabetes Mellitus Tipe 2 \\ dengan Pendekatan DEE Berbasis Health Promotion Model)
}

\author{
Nian Afrian Nuari \\ STIKES Karya Husada \\ Jalan Soekarno Hatta No. 7 \\ E-mail: nian.afrian@yahoo.co.id
}

\begin{abstract}
ABSTRAK
Pendahuluan. Diabetes Mellitus (DM) merupakan salah satu penyakit kronis yang memerlukan kemampuan individu dari pasien untuk mematuhi penatalaksanaan penyakitnya yang dianjurkan oleh dokter. Tujuan penelitian ini untuk menganalisis pengaruh penerapan diabetes empowerment education terhadap self empowerment dan kualitas hidup pasien DM tipe 2. Metode. Penelitian ini menggunakan desain quasy eksperiment with non randomized control group pretest post test design. Sampel yang digunakan sebanyak 32 responden dibagi menjadi kelompok kontrol dan perlakuan dengan teknik purposive sampling. Pengumpulan data self empowerment dengan kuesioner Diabetes Empowerment Scale (DES), sedangkan kualitas hidup menggunakan Diabetes Quality of Life (DQoL). Hasil penelitian kemudian dilakukan analisis dengan Wilcoxon Sign rank test dan Mann Whitney test dengan signifikansi 0,05. Hasil. Hasil penelitian menunjukkan ada perbedaan self empowerment dan kualitas hidup pasien DM tipe 2 sesudah perlakuan. Analisis dengan Mann Whitney terdapat perbedaan self empowerment kelompok kontrol dan perlakuan $(\mathrm{p}=0,029)$ dan ada perbedaan kualitas hidup pada kelompok kontrol dan perlakuan $(p=0,022)$. Itu berarti terdapat pengaruh terhadap self empowerment dan kualitas hidup. Diskusi. Diabetes empowerment education meningkatkan self empowerment dan kualitas hidup pada pasien DM.
\end{abstract}

Kata kunci: diabetes, education, self empowerment, kualitas, hidup, DEE, HPM

\section{ABSTRACT}

Introduction. Diabetes Mellitus (DM) is a chronic disease that requires individual ability of patients to adhere treatment of the disease recommended by doctors. The purpose the study was to analyze the effect of diabetes empowerment education to self empowerment and quality of life of patients with type 2 DM. Method. This study used quasy experiment design with non randomized control group pretest post test design. Total sampel was 32 respondents divided into control group and experiment group, sample recruited by purposive sampling. Data were collected using questionnaire with DES (Diabetes Empowerment Scale) and DQoL (Diabetes Quality of Life). Data were then analyzed using Wilcoxon Sign rank test and Mann Whitney with level of significance of 0.05. Result. The results showed that there were differences in self empowerment and quality of life of patients with type 2 DM after intervention. Mann Whitney analysis result's showed that there are differences in self empowerment between control and experiment groups $(p=0.029)$ and there was a difference in the quality of life between control and experiment groups $(p=0.022)$. It can be referred from it that DEE influences self empowerment and quality of life of type 2 DM patients. Discussion. It can be concluded that diabetes empowerment education increasing self empowerment and quality of life of patients with DM type 2.

Keywords: diabetes, education, self empowerment, quality of life, DEE, HPM

\section{INTRODUCTION}

Diabetes Mellitus (DM) is a chronic disease that requires individual ability of patients to adhere to treatment of the disease are recommended by doctors. Number of patients with DM from year to year tends to increase. Results of statistical reports the International Diabetes Federation (IDF, 2010), the number of patients with type 2 diabetes has increased from year to year, and there are about 230 million diabetics in the world. Each year the incidence rose 3 percent or an increase of 7 million people each year. Data on the PHC Bendo preliminary study indicates that there are $40 \%$ of people with Type 2 diabetes who have less knowledge. This shows that there are people with diabetes who do not have sufficient knowledge about diabetes self-management, or people with diabetes who knows the DM and DM management but do not want to implement 
it, or diabetes who knew about DM and DM management but do not want to apply it. DM is a disease that is not curable, but can be controlled to reduce the risk of complications that can lead to death. Healthy lifestyle with meal planning and physical exercise can keep the glucose levels of patients in order to stay in control. Diabetes should be able to manage the diabetes to prevent complications by maximizing existing aspects within themselves to determine the best option for improving their health status.

Individuals with DM have a great responsibility to organize themselves to perform maintenance on the disease. The ability of individuals to have control over their own lives and make choices about health called self empowerment. Self empowerment in patients with diabetes is also called psychological empowerment in which the capacity of the individual is realized to build confidence, increase self-esteem and develop coping mechanisms to improve personal skills. Efforts to improve the self-empowerment in patients with DM should be supported by good promotion strategy of health workers, especially nurses. Empowerment strategies developed in diabetes to increase their control of the disease by means of increasing physical activity, improving healthy eating and increasing mental health a better and prosperous. A nurse must be able to integrate all the aspects that support the environmental aspects of the individual and capable of empowering people with diabetes to implement the five pillars in the management of diabetes mellitus with use of the runway models of health promotion (Health promotion models). Health promotion model is a model for nurses to explore the complex biopsychosocial processes that motivate individuals to behave in certain ways, which aimed to improve the health status (Tomey \& Alligood, 2006).

Karter (2008) found 50\% of patients with type 2 diabetes do not yet understand about the disease and the understanding of disease type II diabetes is very important in the treatment effort. Lack of knowledge of type 2 DM patients provides opportunities for nurses in providing educative role of the diabetic patient. McNamara et al (2010) educational intervention is helpful in avoiding complications in patients with type 2 diabetes mellitus.

Diabetes Quality of Life (DQoL) is the result reported by patients include physical aspects, functions, social and emotional state of a person with DM (Borrot \& Bush, 2008). One factor that encourages the need for consideration and measurement of quality of life, particularly in patients with diabetes is diabetes mellitus is a chronic disease that can not be cured but if well controlled can inhibit or prevent complications. Lower quality of life and psychological problems may worsen metabolic disorders directly through hormonal stress and indirectly through poor compliance. This condition needs to be handled effectively through the empowerment approach to the patient is able to perform its diabetes disease management to prevent complications. Until now there has not been many research studies that examine self-empowerment in patients with DM. Strategies to achieve maximum selfempowerment in patients with diabetes also have not been studied primarily by using the method of diabetes empowerment education.

The purpose of this study was to identify personal factors, perceived benefits of action, perceived barriers to action in Type 2 diabetic patients in the health center Bendo Kediri region and analyze the effect of the application of diabetes education on self-empowerment empowerment and quality of life of patients with Type 2 diabetes in the region Bendo district health center Kediri.

\section{METHODS}

Type of research was quasy experiment with non-randomized control group pretestposttest design. The subjects comprised two groups: control and treatment groups were measured pre-test and post-test on selfempowerment and quality of life after being given the diabetes empowerment education. Self empowerment was measured using a questionnaire Diabetes Empowerment Scale (DES) while quality of life was measured with the Diabetes Quality of Life questionnaire 
(DQoL) are modified according to the characteristics of the study subjects. The population under study was all patients with Type 2 DM region Puskesmas Bendo Pare Kediri in May 2014 to August 2014 sampling technique in this study using purposive sampling with a sample size of 16 people per group. Confounding variables in this study were personal factors (age, sex, education), perceived benefits, perceived barriers. Data collection was carried out for 1 month. Data analysis was done with the Wilcoxon signed rank statistical test and the Mann-Whitney test of significance of 0.05 .

\section{RESULTS}

The results of the data collection showed that of 32 respondents, divided into a control group and a treatment group obtained mostly 51-60 years old, earn between 1.000.000 Rp 2,000,000, female. Long suffered from diabetes in the control group largely 1- 5 years whereas in the treatment group suffered from diabetes in 6-10 years. Most education elementary education control group, while the treatment group educated junior high. Components of other health promotion model that perceived benefits and perceived barriers. In the control group showed the majority of respondents have a negative perceived benefits and perceived barriers that are obstacles. In the treatment group showed the majority of respondents have a positive perceived benefits and perceived barriers that are not barriers.

Based on Table 1 showed that the treatment group was obtain an increase in self-empowerment than enough to either the 2 respondents, and increase self-empowerment of the poor category to quite as much as 6 respondents and respondents who still have less self-empowerment by 1 person. Self empowerment in the control group showed similar results both pre-test and post-test scores as only a change without a change in category.

Based on Table 2 indicate that the treatment group contained $87.5 \%$ the quality of life is that there are two respondents who experienced improved quality of life is to high and 4 respondents who experienced improvement of quality of life for low to moderate. Whereas the control group did not obtain an increase in the category of quality of life but only an increase in the score as much as 3 respondents, 4 respondents who experienced a decline in scores and scores 9 respondents who remained.

Table 3 shows the results of statistical tests on the treatment and control groups with the Mann-Whitney test $\mathrm{z}$ value obtained count 2.1780 .029 and $\mathrm{p}<0.05(\alpha)$, meaning that there are differences in the pre-test and post-test self-empowerment among treatment groups and control group so that there is the effect of diabetes education on self-empowerment empowerment.

Table 4 shows the results of MannWhitney $\mathrm{z}$ values obtained count -2.291 0.022 and $\mathrm{p}<0.05(\alpha)$, meaning that there are differences in the pre-test and post-test quality of life between the treatment and control groups so that there is an influence of diabetes empowerment education on quality of life.

Table 1. Cross Tabulation of Pre-Test and Post-Test Self-Empowerment in the Treatment Group in The Puskesmas Bendo Kediri

\begin{tabular}{|c|c|c|c|c|c|c|c|c|c|}
\hline \multirow{3}{*}{\multicolumn{2}{|c|}{$\begin{array}{l}\text { Self Empowerment } \\
\text { Treatment Group }\end{array}$}} & \multicolumn{6}{|c|}{ Post Test } & \multirow{2}{*}{\multicolumn{2}{|c|}{ Total }} \\
\hline & & \multicolumn{2}{|c|}{ High } & \multicolumn{2}{|c|}{ Medium } & \multicolumn{2}{|c|}{ Low } & & \\
\hline & & $\mathbf{F}$ & $\%$ & $\mathbf{F}$ & $\%$ & $\mathbf{F}$ & $\%$ & $\mathbf{F}$ & $\%$ \\
\hline \multirow[t]{3}{*}{ Pre Test } & High & - & - & - & - & - & - & - & - \\
\hline & Medium & 2 & 12,5 & 7 & 43,75 & - & - & 9 & 56,25 \\
\hline & Low & - & - & 6 & 37,5 & 1 & 6,25 & 7 & 43,75 \\
\hline Total & & 2 & 12,5 & 13 & 81,25 & 1 & 6,25 & 16 & 100 \\
\hline
\end{tabular}


Increasing Self Empowerment and Quality of Life of Patients (Nian Afrian Nuari)

Table 2. Cross Tabulation of Pre-Test and Post-Test Quality of Life in The Treatment Group in The Puskesmas Bendo Kediri

\begin{tabular}{|c|c|c|c|c|c|c|c|c|c|}
\hline \multirow{3}{*}{\multicolumn{2}{|c|}{$\begin{array}{c}\text { Quality of Life Treatment } \\
\text { Group }\end{array}$}} & \multicolumn{6}{|c|}{ Post Test } & \multirow{2}{*}{\multicolumn{2}{|c|}{ Total }} \\
\hline & & \multicolumn{2}{|c|}{ High } & \multicolumn{2}{|c|}{ Medium } & \multicolumn{2}{|c|}{ Low } & & \\
\hline & & $\mathbf{F}$ & $\%$ & $\mathbf{F}$ & $\%$ & $\mathbf{F}$ & $\%$ & $\mathbf{F}$ & $\%$ \\
\hline \multirow[t]{3}{*}{ Pre Test } & High & - & - & - & - & - & - & - & - \\
\hline & Medium & 2 & 12,5 & 10 & 62,5 & - & - & 12 & 75 \\
\hline & Low & - & - & 4 & 25 & - & - & 4 & 25 \\
\hline Total & & 2 & 12,5 & 14 & 87,5 & - & - & 16 & 100 \\
\hline
\end{tabular}

Table 3. Results of The Mann-Whitney Test of Self Empowerment in The Treatment Group and The Control Group

\begin{tabular}{cccc}
\hline No & \multicolumn{1}{c}{ Variable } & Z & p \\
\hline 1 & Self Empowerment Treatment Group & & $-2,178$ \\
\cline { 1 - 1 } 2 & Self Empowerment Control Group & & 0,029 \\
\hline
\end{tabular}

Table 4. Results of The Mann-Whitney Test of Quality of Life in The Treatment Group and The Control Group

\begin{tabular}{cccc}
\hline No & \multicolumn{1}{c}{ Variable } & Z & $\mathrm{p}$ \\
\hline 1 & Quality of Life Treatment Group & & $-2,291$ \\
\hline 2 & Quality of Life Control Group & 0,022 \\
\hline
\end{tabular}

\section{DISCUSSION}

Health promotion component of the model consists of several aspects of personal factors, perceived benefits of action, and perceived barriers to action. Components of personal factors in DM patients include age, gender, and education. The results showed that most of the obtained characteristics of age in the control group the majority $(56.25 \%)$ aged 51-60 years, whereas in most of the treatment group (62.5\%) aged 51-60 years also. The age ranges of respondents either the control group or the treatment of the youngest age group 45 years to 70 years of age. Smeltzer \& Bare (2004) suggests type 2 diabetes is a type of diabetes that is most abundant at around $90-95 \%$ of all patients with DM and widely experienced by adults over 40 years of age. This is due to insulin resistance in type 2 diabetes is likely to increase in the elderly (4065 years), in addition to a history of obesity and the presence of hereditary factors. Age affects the risk and incidence of type 2 diabetes is closely associated with the age increase in blood sugar levels, thereby increasing age the prevalence of type 2 diabetes is increasing. WHO declared after the age of 30 years, the blood glucose level will rise $1-2 \mathrm{mg} / \mathrm{dL} /$ year during fasting will increase from 5.6 to 13 $\mathrm{mg} / \mathrm{dL}$ at 2 hours after eating (Suyono, 2011).

This result is consistent with the theory that the majority of respondents aged over 40 years with fluctuating blood sugar levels. Aging process takes place in the human body resulting in anatomical changes, physiological and biochemical disturbances that will improve glucose tolerance and insulin resistance. The results showed that most of the sexs in control and treatment groups as the majority (93.75\%) were female. This is in line with several studies that showed that most patients with type 2 diabetes are female. Research Gautam et al., (2009) on cross sectional quality of life of patients with type 2 diabetes in India, most of the respondents were female. WHO (2006) stated, DM is one of the diseases with the highest incidence in Indonesia, making Indonesia ranked 6th in the world. Various studies indicate that the incidence of diabetes in women more than men. Some risk factors 
such as obesity, lack of exercise, age and history of diabetes during pregnancy cause a high incidence of diabetes in women.

The third personal factor is the education factor. The results showed the majority of data $(56.25 \%)$ had elementary education in the control group, whereas in most of the treatment group (31.25\%) junior high school education. This is in line with research Mier et al., (2008) in a cross-sectional study in patients with type 2 diabetes found most respondents with low education. Goz et al, (2006) in his study in hospital diabetes clinic Turkey, most of the low-educated respondents. Reviews the theory does not explain the link between education and disease type $2 \mathrm{DM}$ results can be assumed that the level of education affects a person's behavior in seeking care and treatment of the disease, as well as choose and decide the action or therapy that will be undertaken to address the health problems.

Components of other health promotion model are the perceived benefits of the action are a patient's perception of treatment benefit or healthy behavior in order to achieve commitment to change behavior. Perceived barriers of action are a patient's perception of treatment barriers or healthy behavior so that the behavior does not change. Based on the results obtained in the control group the majority $(62.5 \%)$ on the components of perceived benefit obtained negative results, while the components are no barriers perceived barrier obtained at $56.25 \%$. This is in contrast with the data in the treatment group in which the majority $(56.25 \%)$ on the perceived benefits showed positive components, while the component of perceived barriers obtained no barriers at $68.75 \%$. This factor is very important perceived benefits identified if the patient wants to change the behavior of DM into healthy behaviors that support the treatment of diabetes disease endured. Someone who feels a behavior that is not beneficial to him then someone will likely not be motivated to do so, whereas the perceived barrier factors should also be identified so that the obstacles perceived barriers that people with diabetes in making a health behavior change are able to look for solutions that do not hamper people with diabetes to make a commitment to change health behavior in order to control their blood sugar.

The results of the statistical test with Mann-Whitney showed there are differences in the pre-test and post-test self-empowerment which significantly between treatment group and control group. If seen in appendix tabulation can be concluded that in the treatment group and the control at the same have increased but the control group had increased very little so it tends to stay. This suggests that self empowerment treatment group further increased after the implementation of diabetes education empowerment. The results of the study if associated with the characteristics of respondents by age shows that most respondents in the control group and the treatment has aged 51-60 years who have enough self-empowerment and less category. These data are consistent with research Tol et al., (2012) in a cross-sectional study of factors affecting diabetes empowerment in Iran stating that the diabetes empowerment has a significant relationship with age $(\mathrm{p}<0.001)$. Tol et al., Stating age had no significant relationship with aspects of dissatisfaction and readiness assessment for change contained in the Diabetes Empowerment Scale (DES). It can be assumed that the age factor also determines the ability of individuals to have their own control of the decision to choose the best alternative for her health. Elderly individual with age affects cognitive ability in analyzing the best choice for health and have limited physical abilities when looking at health care and health personnel.

Educational background of the respondents in the control group and the treatment group mostly elementary education and have enough self-empowerment category, whereas respondents with a high school education have a good self-empowerment category. This is consistent with research Tol A et al., (2012) which states that the level of education has a significant relationship with the elements contained in the DES include the management of psychosocial aspects of diabetes $(r=0.078, p=0.04)$, dissatisfaction and readiness assessment change $(r=$ 
0.076, $\mathrm{p}=0.04)$, and the determination and achievement of objectives with diabetes ( $\mathrm{r}$ $=0.09, p=0.01)$. It can be assumed that the higher the education, the diabetes self-owned empowerment will also be better. Intellectual abilities possessed by individuals will affect the ability of the individual acceptance of something. Individuals will be more mature the process of change that was in him that are more receptive to outside influences positive that readiness for change either.

Self empowerment treatment group had enough category that most suffered from diabetes for 6-10 years. A Toll et al., (2012) states that the long suffering from diabetes has a significant connection with aspects of assessment dissatisfaction and readiness to change $(r=-0.1, p=0.009)$. It can be assumed that the longer a person suffering from diabetes, the lower the individual's readiness to change. Individuals feel comfortable with the disease because there has been a process of adaptation that is long enough so that tends to be less sensitive to accept the changes against him.

Perceived benefits in the treatment group the majority $(56.25 \%)$ had a positive category. The treatment group had an increase in self-empowerment than enough to either the 2 respondents, and increase selfempowerment of the poor category to quite as much as 6 respondents. This suggests that individuals who have a positive perception of the advantages of doing healthy behavior will increase the commitment of these individuals so as to improve self empowerment on him. Perceived barriers in the treatment group also showed the majority $(68.75 \%)$ had no barriers category. The call indicates that the perception of the individual that does not hinder in making a commitment to change the behavior of selfempowerment is able to change in him.

The main objective of the management of chronic diseases such as type 2 diabetes is to encourage patients to take greater responsibility for their care, and to perform maintenance on their own. Health promotion has been done at the health center by a team of health promotion Bendo appointed by the head of the health center. Health promotion include the provision of information about disease management DM and DM were performed in general and poly posyandu elderly health centers in the working area. Counseling conducted by a team of health promotion less regularly each month, there is no follow-up after an extension of the team Promkes and liveliness participants during counseling are not maximized. Extension needs to be done to implement empowerment strategies that increase the activity of the participants counseling, can improve the patient's ability to make choices and changes in behavior that are expected to come from the patient's own internal factors.

Health workers and academics have introduced self-empowerment as an important factor in managing chronic disease. When it comes to individual health facilities need to be empowering with an innovative approach that attempts to improve the ability of patients to actively understand and influence the daily life and their health status. This approach helps patients with diabetes make informed decisions regarding the care plan of their own disease. Effective patient empowerment can be achieved by providing the knowledge and skills necessary to perform maintenance on the disease. Diabetes education is an educational empowerment given to diabetic patients with empowerment approach (empowerment) that focuses on the patient (Henshaw, 2006). Empowerment can be called also with something that focuses on collaborative care in which patients or health care providers and patients make decisions together (Borrot $\&$ Bush, 2008). The purpose of diabetes empowerment education is to improve the patient's ability to self-manage diabetes and reduce complications of the disease so as to improve the quality of life. The main concept of empowerment is information, communication and health education (WHO, 2006).

Elements of self-empowerment in patients with DM consists of psychosocial aspects of patients with DM, assessment dissatisfaction and readiness to change, and setting and achieving goals diabetes used to assess the patient's perception of the ability to set realistic goals and achieve them with 
overcoming obstacles in achieving goals with diabetes (Anderson \& Funnel, 2000). The third element relates to the personal factors which are owned diabetic patient such as age, gender, and income owned by people with diabetes. In addition to these factors there are also factors that predispose a person to develop empowering himself from the perception aspect of doing a behavior based on the benefits or disadvantages of such action. The results of data analysis in the treatment group and the control with the Mann-Whitney test showed there are differences in the pre-test and post-test mean quality of life between the treatment group and the control group, so that the treatment group had improved quality of life better after the implementation of diabetes empowerment education.

The results showed that the quality of life in the control group and the treatment of most categories of being and having 51 to 60 years of age. Yusra (2012) in his research suggests that the relationship between age and quality of life showed a negative pattern which means that increasing age decreases the quality of life of the respondents $(\mathrm{p}=$ 0.034, $r=-0.194)$. The study of Anderson et al., (2003) also states that the addition of a negative effect of age on the quality of life of patients with type 2 diabetes mellitus Individuals experiencing rapid physiological changes after the age of 40 years. It can be assumed that with age there is a change one's physical, psychological and intellectual. This will cause a reduction in the ability of selfcare in the management of DM. Decreased function of the body would also reduce the ability of DM disease management so that it will easily happen kesehtana interference that can degrade the quality of life.

Improved quality of life in the treatment group was found more female respondents because the majority of respondents were female. In Issa \& Baiyewu research (2006) on the quality of life of patients with type 2 diabetes, that gender is not associated with a lower quality of life. Yusra (2012) also stated that there is no significant relationship between quality of life with gender ( $\mathrm{p}=$ 0.775). It is added again by Reid \& Walker
(2009) in his research proves that one of the demographic factors that do not contribute to lower quality of life is sex. It can be assumed that men and women have the same ability in the management of diabetic patients. They also have the same attitude, use of coping and behaving as expected to manage the disease.

The results showed an increase in the quality of life experienced by respondents with high school education compared to respondents who had elementary education. Yusra research results (2012) states there are significant differences in the quality of respondents with high education and low education. In line with the opinion of Notoatmodjo (2003), the level of education is an indicator that a person has formal education in a particular field. Someone with a good education, the more mature the process of change in him, making it easier to accept outside influences are positive, objective, and open to a variety of information, including health information. It can be assumed that education is an important factor in understanding the disease, self-care, diabetes management and blood sugar control. Patients with higher education will be able to develop constructive coping mechanisms in the face of stressors as a good understanding of the information. DM patients who have received diabetes education empowerment make positive individual and will take appropriate action and beneficial to himself so that quality of life improved.

Quality of life in the treatment of most of the respondents had medium category with a long time suffered from diabetes for 6 to 10 years. This is consistent with studies Reid \& Walker (2009) that there is a relationship between long-suffering DM with the quality of life of respondents with a negative relationship patterns. It can be assumed that the longer suffer from diabetes decreases the quality of life of patients. DM disease suffered by the patient can lead to anxiety patients, so the longer the time suffering from a disease that can cause continuous anxiety in people with diabetes and will result in the loss of quality of life. Other factors that influence the quality of life in patients with DM is socioeconomic. From the results, the quality 
of life of people with diabetes tends to be lower in respondents who are not working and have income of less than Rp. 1,000,000. In research Gautam et al., (2009), said that the lower quality of life associated with low socioeconomic owned DM patients. Butler (2002) stated that socio-economic status and knowledge about diabetes affect a person to perform self-care management of diabetes mellitus. Socioeconomic limitations in DM patients will also restrict people with diabetes to find information, treatment and care for him so that the quality of life tends to be low.

\section{CONCLUSION}

Diabetes education empowerment can improve self empowerment and quality of life ofpatient with type 2 diabetes.

\section{RECOMMENDATIONS}

Suggestion nurses to further improve health promotion programs by implementing empowerment strategies in conducting health education to patients with diabetes by increasing patient involvement, provide follow-up to the problems experienced by the participants of extension so as to enhance the self empowerment of patients to manage their disease and improve their quality of life.

\section{REFERENCES}

Anderson R.M., Funnell M.M., Fitzgerald J.T., \& Marrero, D.G., 2000, 'The diabetes empowerment scale: a measure of psychosocial self-efficacy,' Diabetes Care Journal. 23(6): 739-743

Anderson R.M, Fitzgerald J.T, Gruppen L.D, \& Funnell M.M 2003, 'The diabetes empowerment scale-short form (DESSF)' Diabetes Care Journal. 26: 1641-1643

Borrot N., \& Bush R., 2008, 'Measuring quality of life among those with type 2 diabetes in primary care'. Healthy Communities Research Centre, The University of Queensland Web site: diakses tanggal 18 Februari 2013 http://www.uq.edu. $\mathrm{au} /$ health/healthycomm/docs/QoL.pdf
Butler, H.A 2002, Motivation: The role in diabetes self management in older adults, Diakses tanggal 1 April 2013 http://proquest.umi.com/pqdwe.

Gautam, Y, Sharma, AK, \& Agarwal 2009, 'A cross sectional study of qol of diabetic patient at tertiary care hospital in delhi' Indian journal of community medicine 34(4), 346-350

Gibson CH 1991 ' A concept analysis of empowerment' Journal Advance Nursing; 16:(3): 354-61

Goz, F., Karaoz, S., Goz, M., Ekiz, S., \& Cetin, I 2007, ' Effect of the diabetic patient's perceived social support on their quality of life' Journal of Clinical Nursing, 16, 1353-1360.

Henshaw, L, 2006, 'Empowerment, diabetes and the national service framework: a systematic review.' Journal of Diabetes Nursing Vol. 10, No.

Isa B.A \& Baiyewu, O 2006, 'Quality of life patient with patient with $\mathrm{dm}$ in a nigerian teaching hospital.' Hongkong Journal Psychiatry, 16, 27-33

Karter, A.J., Stevens, M.R., Gregg, E.W., Brown, A.F., Tseng, C.W., Marrero, D.G., Duru, K., Gary, T.L., Piette, J.D., Waitzfelder, B., Herman, W.H., Beckles, G.L., Safford, M.M., and Ettner, S.L., 2008, ' Educational disparities in rates of smoking among diabetic adults: the translating research into action for diabetes study, Am J Public Health. 2008; 98: 365-370.

McNamara, R., Robling, M., Hood, K., Bennert, K., Channon, S., Cohen, D., Crowne, E., Hambly, H., Hawthorne, K., Longo, M., Lowes, L., Playle, R., Rollnick, S., Gregory, J.W., 2010, 'Development and evaluation of a psychosocial intervention for children and teenagers experiencing diabetes (DEPICTED).' BMC Health Services Research 2012, 12:36, http://www. biomedcentral.com/1472-6963/10/36al,

Mier, N., Alonso, A.B., Zhan, D., Zuniga, M.A., \& Acosta, R.I 2008, 'Health related quality of life in a binational population with diabetes at the TexasMexico border' Rev Panam Salud Publica, 23(3), 154-163 
Notoatmojo, S 2005, Metode Penelitian Kesehatan, Rineka Cipta, Jakarta

Puskesmas Bendo 2014, Data kunjungan pasien puskesmas bendo. Puskesmas Bendo Kabupaten Kediri

Reid, M.K.T., \& Walker, S.P. 2009, 'Quality of life in Caribbean youth with diabetes.' West Indian Med Journal, 58 (3) 1-8

Smeltzer, S.C., Bare, BG., Brunner \& Sudarth's 2004, Textbook of medical surgical nursing 10th edition. Volume 2. Lippincot \& Wilkins, Philadelphia

Suyono, S. 2011, 'Penatalaksanaan DM terpadu.' Patofisiologi DM. Edisi ke-2. Balai Penerbit FKUI, Jakarta

Tol, A., Shojaeezadeh D., Sahrifirad G., Alhani F., \& Tehrani MM 2012, 'Determination of empowerment score in typr 2 diabetes patients and its relation factors' $J$ Pak Med Assoc. 2012 Jan;62(1): 16-20
Tol, A., Baghbanian A., Shojaeezadeh D., Azam K., Shahmirzadi S., \& Asfia A 2012, 'Empowerment assessment and influential factors among patients with type 2 diabetes' Journal of Diabetes Metab Disord. 2013; 12: 6. Published online 2013 January 19

Tommey, A.M., \& Alligood, M.R. 2006, Nursing theorists and their work. Six Edition. St. Louis Missouri, Mosby

World Health Organization 2006, 'Definition, diagnosis and clasification of diabetus mellitus and its complications.' Report a WHO Consultation. WHO, Geneva

Yusra, A 2012 'Hubungan dukungan keluarga dengan kualitas hidup pasien DM tipe 2 'Thesis FIK UI. Jakarta: FIK UI 